\title{
Fungi Associated with the Stalk Rot Complex of Pearl Millet
}

\author{
J. P. Wilson, USDA-ARS Crop Genetics and Breeding Research Unit, University of Georgia Coastal Plain Experi- \\ ment Station, Tifton 31793
}

\begin{abstract}
Wilson, J. P. 2002. Fungi associated with the stalk rot complex of pearl millet. Plant Dis. $86: 833-839$

Stalk rot is frequently observed in maturing, rust-infected pearl millet (Pennisetum glaucum). Fungi were isolated from internal stalk tissue, and their association with node discoloration and rust infection at different stages of plant maturity was determined to gain a greater understanding of stalk rot etiology. In 1995, stalk rot was observed in a breeding population of pearl millet. Stalks of 10 rust-infected plants were collected on each of three dates during grain fill. Frequency of symptomatic, discolored nodes was higher in the later sampling dates. Stalk sections from 119 discolored nodes were surface sterilized and plated onto agar media. Fungi most frequently isolated from symptomatic nodes were Bipolaris setariae (isolated from $47 \%$ of discolored nodes), Fusarium semitectum (28.6\%), and F. moniliforme sensu lato (23.5\%). Isolation frequency of these fungi differed $(P<0.05)$ with sampling date. In 1996 and 1997, the hybrid HGM 100 was evaluated at two dates of planting in each year. Ten stalks were sampled at each of four growth stages: panicle emergence, stigma emergence, milk, and hard dough. A total of 140 stalks was assessed for rust severity and for internal stalk discoloration at the nodes. The frequency of discolored nodes increased with plant maturation and was correlated $(P<0.01)$ with severity of rust infection. All nodes were plated on an agar medium, and a total of 1,512 isolates from 30 fungal genera or species were isolated from the 1,540 nodes of the sampled stalks. F. moniliforme was isolated most frequently (isolated from $23.5 \%$ of all nodes). Frequency of isolation of $F$. moniliforme from nodes within stalks increased with advancing maturity in the earlier dates of planting, but was not correlated with rust infection. B. setariae (isolated from $9.2 \%$ of all nodes) was more frequently isolated from plants at the dough stage in three plantings, and was correlated $(P<0.01)$ with rust severity. Trends in the frequency of isolation of other fungi were inconsistent between planting dates or among growth stages. Frequency of isolation of $F$. semitectum (isolated from $11.0 \%$ of all nodes) and Alternaria spp. (6.9\% of all nodes) was correlated $(P<0.05)$ with rust severity. Frequency of isolation of Curvularia spp. (isolated from $7.0 \%$ of all nodes) was negatively correlated $(P<0.05)$ with rust severity. Isolation of Alternaria spp. and B. setariae was more frequently associated with node discoloration than was isolation of the other fungi. Stalk rot of pearl millet is the result of a complex of several fungi whose incidence was influenced by rust infection, plant maturation, and environmental factors associated with differences among years and dates of planting.
\end{abstract}

Current and impending water deficits and restrictions on agricultural irrigation are increasing the need for drought-tolerant crops. Pearl millet (Pennisetum glaucum (L.) R. Br.) hybrids are presently grown for temporary summer grazing in the southeastern United States, and plant breeding research is being conducted by the USDAARS at Tifton, GA, to develop hybrids for grain production. Modifying the harvest index of the plant has resulted in the de-

Corresponding author: J. P. Wilson

E-mail: jwilson@tifton.cpes.peachnet.edu

Cooperative investigation of the USDA-ARS and the University of Georgia, College of Agricultural and Environmental Sciences, Agricultural Experiment Station.

Accepted for publication 28 March 2002.

Publication no. D-2002-0614-03R

This article is in the public domain and not copyrightable. It may be freely reprinted with customary crediting of the source. The American Phytopathological Society, 2002. velopment of a promising feed grain crop adapted to the drought-prone and relatively infertile soils of the Southern Coastal Plain region.

The grain hybrid HGM 100 (4) was grown commercially in the southeastern United States from 1991 to about 1997. At the time of its release, the rust resistance of HGM 100, conferred by the $R r_{1}$ gene, was highly effective. Selection for virulence in the Puccinia substriata Ell. \& Barth. var. indica Ramachar \& Cumm. population (18) occurred quickly, and HGM 100 was ultimately removed from the market as a result of yield instability associated with rust susceptibility. Research and breeding efforts have continued, and new hybrids are currently in advanced evaluation prior to release.

During the period in which HGM 100 was grown, some growers and extension specialists reported problems with stalk rot and lodging. Severe rust infection is known to exacerbate lodging caused by stalk rots $(25,26)$; however, no information is available concerning the identity of fungi asso- ciated with lodged pearl millet stalks and the relationship of their occurrence with rust infection. In the absence of rust infection, isolations from mature stalks of HGM 100 with limited symptoms of stalk rot most commonly yielded Fusarium semitectum Berk \& Ravenel, F. moniliforme Sheldon, $F$. graminearum Schwabe, Alternaria spp., and Nigrospora spp. (24). The identification of fungi isolated from mature stalks is of limited value because it does not provide insight into the progression of fungal colonization through the season, or the relative pathogenicity and competitive ability of these fungi.

Experiments were conducted to gain a greater understanding of the etiology of stalk rot of pearl millet. The objectives of this study were to identify the fungi that colonize stalks, to determine changes in their frequency of isolation from and distribution within stalks during the latter stages of plant maturity, and to determine the association of specific fungi with rust infection and discoloration of the internal node tissue.

\section{MATERIALS AND METHODS}

Initial isolations. Stalk rot, expressed as external stalk discoloration and lodging, was observed within a genetically heterogeneous breeding population of pearl millet grown at the University of Georgia's Coastal Plain Experiment Station at Tifton in 1995. Rust was prevalent within the population, but the severity of infection was not recorded. Samples were taken to determine fungal pathogens associated with stalk rot. Ten rust-infected stalks at the grain fill stage with external symptoms (discolored and collapsing tissue) of stalk rot were cut at ground level on 26 and 31 October and 7 November 1995. Stalks were split lengthwise. The presence of brown or gray discoloration of the internal tissue at the nodes, and the node position (node $1=$ lowest node, increasing node numbers indicate nodes successively higher up the stalk) of discoloration were recorded. A 2- to 3-cm-long section of the stalk, including each discolored node, was excised, surface-disinfested in $0.5 \%$ $\mathrm{NaOCl}$ for $5 \mathrm{~min}$, and plated onto $\mathrm{V} 8$ juice agar amended with 500 ppm of both chlortetracycline and nalidixic acid. Plates were incubated at $23^{\circ} \mathrm{C}$ under continuous fluorescent light for approximately 5 days. Fungi isolated from nodes were transferred to V8 juice agar for identification. Isolates of Fusarium species were transferred to potato dextrose agar, and species were 
identified by conidium and conidiophore morphology, and by cultural characteristics of the developing colonies (8). Other fungi were identified based upon cultural, mycelial, conidial, conidiophore, or sporocarp characteristics as described in the literature $(1,3,6,9,12,16,17)$.

Changes in frequency of node discoloration were analyzed using the general linear model of SAS (SAS Institute, Cary, NC). Data for percentage of discolored nodes from each stalk were regressed against date of sampling (first date = day 0), and the hypothesis that the slope equaled zero was evaluated by a $t$ test. Data for frequency of node discoloration and frequency of fungal isolation from discolored nodes were analyzed by analysis of variance, and sources of variation for sums of squares were partitioned into stalk (replication), sampling date, node position, and date $\times$ node position interaction.

Effects of growth stage and date of planting. The grain hybrid HGM 100 was planted at the Coastal Plain Experiment Station at Tifton, GA, on 12 July and 5 August 1996, and 2 July and 21 August 1997. The early and late plantings within
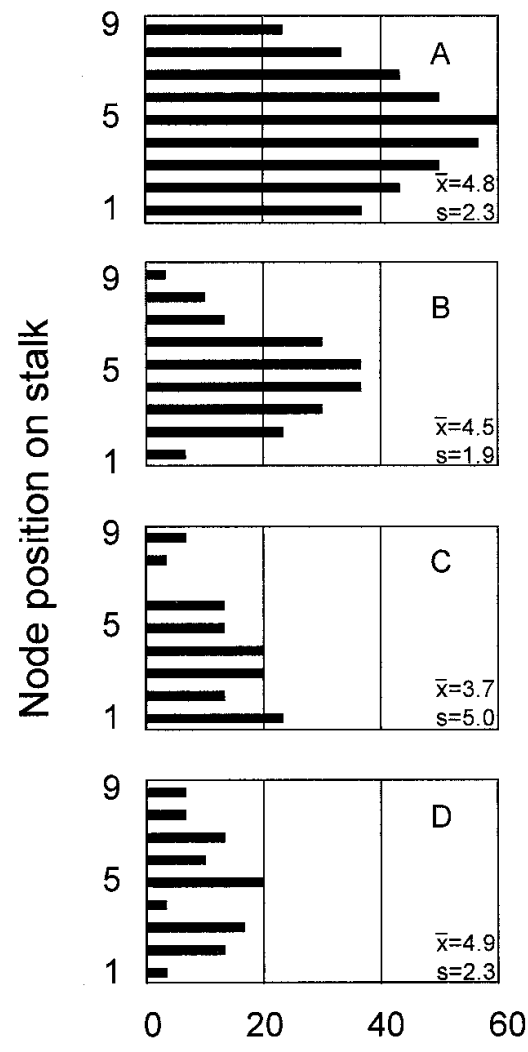

Incidence at node (\%)

Fig. 1. Distributions of discolored nodes in pearl millet stalks infected with rust, and isolations of three predominant fungi from the discolored nodes. $\mathbf{A}=$ discolored nodes, $\mathbf{B}=$ Bipolaris setariae, $\mathbf{C}=$ Fusarium semitectum, and $\mathbf{D}$ $=F$. moniliforme. Node $1=$ lowest node on the stalk and node $9=$ highest node. Values are means of observations from 10 stalks collected at each of three dates in 1995. each season were made to provide opportunity for the crop to mature under environmental conditions that varied in their conduciveness for rust development. At each planting date, five replications of 20m-long, two-row plots were planted at 2.8 $\mathrm{kg} \mathrm{ha}^{-1}$. Row spacing was $0.7 \mathrm{~m}$ within and $1.3 \mathrm{~m}$ between plots. Plots were established on Tifton loamy sand (fine-loamy, silicaceous, thermic Plinthic Kandiudults), and fertilizer (5-10-15) was applied infurrow at planting at the rate of $280 \mathrm{~kg} \mathrm{ha}^{-1}$.

One plant from each replication was selected randomly and dug at each of four growth stages: initial panicle emergence, stigma emergence, milk (early grain fill), and hard dough (late grain maturation). To obtain plants at different growth stages, samples were taken at approximately 1week intervals. Specific dates ranged from 30 August to 25 September, and 18 September to 16 October for the two dates of planting in 1996, and from 21 August to 9 September, and 5 October to 13 November for the two dates of planting in 1997. After the first sampling within a replication, subsequently selected plants were at least 1 $\mathrm{m}$ from any previously sampled plant. Plants were dug with roots, the roots were washed in water, and the two main stalks were separated. Rust severity of each stalk was estimated visually as the percent foliage infected or killed by rust infection. The stalks were placed in plastic bags and remained in a cold room $\left(5^{\circ} \mathrm{C}\right)$ for up to 2 weeks until processing in the lab.

Each stalk was split lengthwise and the nodes were assessed for the presence of discolored tissue. The location of the discolored nodes in each stalk was recorded, where node 1 = lowest node, increasing node numbers indicate nodes successively higher up the stalk, and node position $0=$ the basal portion of the stalk. In contrast to the 1995 procedure, both discolored and asymptomatic nodes were surface-disinfested and plated as described above. Fungal isolation and identification procedures were identical to those described above.

Data for rust severity (percent foliage infected) of each stalk, the percentage of discolored nodes per stalk, and percentage of nodes from which a particular fungal species was isolated from each stalk were analyzed. The general linear model procedure of SAS was used for analysis because of missing data; stalks sampled from the first two growth stages of the second planting in 1997 were inadvertently discarded from the cold room prior to evaluation. Many fungi were isolated from nodes, but analyses were limited to fungi that were both suspected pathogens and were isolated from more than $5 \%$ of the nodes over all year by date of planting experiments. Interactions among sources of variation were frequently significant in the analysis of data pooled over experiments, so data were analyzed within each year by date of planting experiment to discern differences among growth stages. Variable means for growth stages within year by date of planting experiments were differentiated by Fisher's least significant difference test. Over all experiments in 1996 and 1997, Pearson's correlation coefficients were calculated between the rust severity of individual stalks and the percentage of nodes from that stalk from which specific fungi were isolated.

Data were summarized graphically by growth stage across years and dates of planting to discern patterns of node discoloration and fungal isolation from within stalks. Over all stalks collected in the experiments, Pearson's correlation coefficients between the presence of discoloration at a node and isolation of a specific fungus from that node were calculated.

\section{RESULTS}

Initial isolations. Each of the 30 stalks examined in 1995 exhibited some node discoloration, and 119 nodes $(44.1 \%$ of the 270 total) were discolored. Frequency of discolored nodes differed among stalks and sampling date $(P<0.01)$, but the effect of node position was not significant $(P=$ 0.07). The relationship between frequency of discolored nodes $(y)$ and sampling date (x) could be described by the equation $y=$ $31.8+2.17 x$. The slope of the regression differed from zero $(P=0.05)$; thus the frequency of discolored nodes increased at the later sampling dates. Node discoloration was distributed throughout the length of the stalks, but the frequency of discoloration was greatest among the central nodes (Fig. 1A). From these 119 discolored nodes, 154 fungal isolates were obtained.

Bipolaris setariae (Saw.) Shoem was the most frequently isolated fungus and was recovered from 57 of the discolored nodes (47.9\% of the nodes plated). Frequency of isolation from discolored nodes differed $(P$ $<0.05$ ) by stalk, sampling date, and node position. Mean isolation frequencies were $56.7,75.0$, and $22.6 \%$ at the three sampling dates $\left(\operatorname{LSD}_{P=0.05}=18.8\right)$. Date by node position interaction effect was not significant. Across all dates, isolations were made more frequently from the central nodes (Fig. 1B).

Fusarium semitectum was recovered from 34 of the discolored nodes $(28.6 \%$ of the nodes plated). Frequency of isolation from discolored nodes differed $(P<0.01)$ by sampling date, and mean isolation frequencies were $10.0,22.2$, and $32.1 \%$ at the three sampling dates $\left(\operatorname{LSD}_{P=0.05}=19.4\right)$. Stalk, node position, and date by node position interaction effects were not significant. Across all dates, isolations were distributed toward the lower nodes of the plant (Fig. 1C).

Fusarium moniliforme was recovered from 28 of the discolored nodes $(23.5 \%$ of the nodes plated). Frequency of isolation from discolored nodes differed $(P<0.05)$ by sampling date, and mean isolation fre- 
quencies were $6.7,38.9$, and $34.0 \%$ at the three sampling dates $\left(\operatorname{LSD}_{P=0.05}=19.0\right)$. Stalk, node position, and date by node position interaction effects were not significant. Across all dates, F. moniliforme tended to be isolated more frequently from the central nodes of the plant (Fig. 1D).

Other, less commonly isolated fungi and their frequency of isolation from nodes plated (in parentheses) included Fusarium chlamydosporum Wollenw. \& Reinking and Nigrospora spp. (7.6\% each), Sclerotium rolfsii Sacc. (3.4\%), Rhizoctonia zeae Voorhees, Curvularia spp., and unidentified species (2.5\% each) and Rhizoctonia solani Kühn (1.7\%). Exserohilum rostratum (Drechs.) K.J. Leonard \& E.G. Suggs, Drechslera dematioidea (Bubak \& Wroblewski) Subram. \& Jain, and Phyllosticta penicillariae Speg. were isolated from $<1 \%$ of the discolored nodes. Frequently, more than one fungus was isolated from a single node.

Effects of growth stage and date of planting. Year, date of planting, growth stage main effects, and two-factor interactions that included those variables were significant in the analysis of variance of rust severity (Table 1). Final rust severities were greater in 1996 than in 1997 (Table 2 ), and severities increased during grain fill in both dates of planting in 1996. Rust infection was minimal in the first date of planting in 1997, and although disease had developed in the second date of planting, there was no increase in severity on plants between the milk and dough stages of maturity.

Discolored nodes were observed in $99.3 \%$ of stalks collected. Incidence of stalks with discoloration did not differ among any of the possible sources of variation in the analysis of variance (Table 1). A mean of $36.5 \%$ of the nodes within stalks were discolored in 1996 and 1997, and frequency of node discoloration differed by nearly all sources of variation in the experiments, except for the date of planting by growth stage interaction (Table 1). The frequency of nodes with discoloration at the different growth stages were similar in both dates of planting in 1996 and increased with plant maturity (Table 2). In 1997, the first date of planting had fewer discolored nodes, but their frequency likewise increased with plant maturity. Over all experiments, a greater frequency of the lower nodes tended to be discolored than upper nodes, and discoloration progressed from the base to the apex as the plants matured (Fig. 2). Frequency of discolored nodes in a stalk was correlated $(r=0.70, P$ $<0.01$ ) with rust severity.

A total of 1,512 isolates from 30 fungal genera or species were isolated from the 1,540 nodes of the sampled stalks. $F$. moniliforme was the most frequently isolated fungus (Fig. 3). It was isolated from $83.6 \%$ of stalks collected, and incidence of stalks infected with $F$. moniliforme did not differ among the sources of variation in the experiments (Table 1). F. moniliforme was isolated from a mean of $23.5 \%$ of the nodes. Frequency of isolation differed between growth stages (Table 1). F. moniliforme was isolated more frequently in the later growth stages only in the first date of planting in both 1996 and 1997 (Table 2). Isolation frequency tended to be correlated with discoloration of the upper nodes of the plant (Table 3). Isolations from the lower nodes were not correlated with the presence or absence of symptoms, and the fungus was commonly isolated from asymptomatic nodes, particularly in earlier growth stages (Figs. 2 and 3). Frequency of isolation for $F$. moniliforme within a stalk was not correlated with rust severity ( $r=$ $-0.03, P>0.05)$.

F. semitectum was isolated from $57.9 \%$ of the stalks collected, and incidence of infected stalks differed between growth stages, and from interactions of growth stage with both year and date of planting (Table 1). Isolation frequency was greater in the later growth stages only in the first date of planting in 1996 (Table 2). F. semitectum was isolated from a mean of $11.0 \%$ of the nodes, and frequency of isolation from the lower nodes tended to be greater (Fig. 3). Frequency of isolation from nodes differed between growth stages and from interactions of year by date of planting, year by growth stage, and date of planting by growth stage (Table 1). As observed with the incidence of stalks with $F$. semitectum, isolation frequency was greatest only in the latter growth stages in the first date of planting in 1996 (Table 2). Differences among growth stages in the other experiments exhibited no trends or were not significant. Although mean node discoloration and isolation frequency increased in the later growth stages (Figs. 2 and 3 ), isolation of $F$. semitectum was rarely correlated with node discoloration (Table 3). Isolation frequency for F. semitectum within a stalk had a low but significant correlation with rust severity ( $r=$ $0.20, P<0.05)$.

B. setariae was isolated from $42.9 \%$ of the stalks collected, and incidence of infected stalks differed between years,

Table 1. Analyses of variance of rust severity (\% of foliage) and incidence, among stalks or among nodes within stalks, of discolored nodes and isolation of specific fungi from stalks of the pearl millet hybrid HGM 100 grown at Tifton, GA, in 1996 and 1997

\begin{tabular}{|c|c|c|c|c|c|c|c|c|c|c|c|c|c|c|}
\hline \multirow{4}{*}{$\begin{array}{l}\text { Source of } \\
\text { variation }\end{array}$} & \multirow[b]{4}{*}{ df } & \multicolumn{13}{|c|}{ Mean squares } \\
\hline & & \multirow{3}{*}{$\begin{array}{c}\text { Rust } \\
\text { severity } \\
(\%)\end{array}$} & \multicolumn{12}{|c|}{ Incidence $(\%)$ of stalks or nodes } \\
\hline & & & \multicolumn{2}{|c|}{ Discoloration } & \multicolumn{2}{|c|}{$\begin{array}{c}\text { Fusarium } \\
\text { moniliforme }\end{array}$} & \multicolumn{2}{|c|}{$\begin{array}{c}\text { Fusarium } \\
\text { semitectum }\end{array}$} & \multicolumn{2}{|c|}{$\begin{array}{l}\text { Bipolaris } \\
\text { setariae }\end{array}$} & \multicolumn{2}{|c|}{ Curvularia spp. } & \multicolumn{2}{|c|}{ Alternaria spp. } \\
\hline & & & Stalks ${ }^{v}$ & Nodes $^{w}$ & Stalks & Nodes & Stalks & Nodes & Stalks & Nodes & Stalks & Nodes & Stalks & Nodes \\
\hline Year & 1 & $2,003 * * x$ & 0 & $2,687 *$ & 2,238 & 1,446 & 3,515 & 10 & $33,596^{* *}$ & 1,456 & 12,630 & $394 *$ & 10,205 & $2,681^{* *}$ \\
\hline \multicolumn{15}{|l|}{ Replication (yr) } \\
\hline Date of planting & 1 & $8,338 * *$ & 98 & $15,976 * *$ & 1,690 & 1,809 & 2,732 & 839 & 1 & 1,029 & $45,276^{* *}$ & $2,201 * *$ & $35,730 * *$ & $4,141^{* *}$ \\
\hline Year*DOPy & 1 & $19,148 * *$ & 0 & $11,260 * *$ & 125 & 2,935 & 3,125 & $117^{*}$ & $8,000^{* *}$ & 575 & $12,500 *$ & $917 * *$ & $55,125^{* *}$ & $5,626 * *$ \\
\hline \multicolumn{15}{|l|}{ Rep*DOP (yr) } \\
\hline$($ error B) & 8 & 75 & 63 & 175 & 1,823 & 623 & 3,802 & 113 & 656 & 214 & 1,760 & 38 & 1,135 & 159 \\
\hline Growth stage & 3 & $12,924 * *$ & 109 & $7,269^{* *}$ & 3,647 & $2,178^{* *}$ & $7,969^{*}$ & $1,130^{* *}$ & $19,401 * *$ & $4,285^{* *}$ & 253 & 56 & $4,694 *$ & $1,097 * *$ \\
\hline Year*GS ${ }^{\mathrm{z}}$ & 3 & $9,821 * *$ & 0 & $1,676^{* *}$ & 83 & 415 & $12,042 * *$ & $779^{* *}$ & $6,125^{*}$ & 434 & $8,542 *$ & $640 * *$ & $9,750 * *$ & $860 * *$ \\
\hline DOP*GS & 3 & $373^{*}$ & 125 & 182 & 1,500 & 458 & $5,875^{*}$ & $870 * *$ & 3,667 & $844 * *$ & 6,167 & $288 * *$ & $15,708^{* *}$ & $1,245^{* *}$ \\
\hline $\mathrm{Yr} * \mathrm{GS} * \mathrm{DOP}$ & 1 & 499 & 0 & $1,222 *$ & 125 & 748 & 125 & 103 & 2,000 & 306 & 0 & 11 & 1,125 & $1,892 * *$ \\
\hline \multicolumn{15}{|l|}{ Rep*GS(yr*DOP) } \\
\hline Stalk & $\begin{array}{r}40 \\
1\end{array}$ & $\begin{array}{r}129 \\
22\end{array}$ & $\begin{array}{l}75 \\
71\end{array}$ & $\begin{array}{l}240 \\
643 *\end{array}$ & 738 & $\begin{array}{r}430 \\
58\end{array}$ & 025 & $\begin{array}{r}140 \\
0\end{array}$ & $\begin{array}{l}1,463 \\
7,143 *\end{array}$ & $\begin{array}{r}187 \\
61\end{array}$ & $\begin{array}{l}2,500 \\
1,143\end{array}$ & $\begin{array}{c}64 \\
294 *\end{array}$ & $\begin{array}{r}1,613 \\
643\end{array}$ & $\begin{array}{l}51 \\
47\end{array}$ \\
\hline Error (error D) & 69 & 25 & 71 & 159 & 1,086 & 259 & 1,521 & 128 & 1,636 & 65 & 2,012 & 54 & 1,223 & 51 \\
\hline
\end{tabular}

${ }^{\mathrm{v}}$ Stalks = incidence (\%) of stalks with discoloration or incidence of stalks from which a particular fungus was isolated.

${ }^{\text {w Nodes }}=$ incidence $(\%)$ of nodes within a stalk with discoloration or incidence of nodes within a stalk from which a particular fungus was isolated.

$\mathrm{x} *$ and $* *$ indicate significance at $P=0.05$ and 0.01 , respectively.

y DOP = date of planting: 12 July and 5 August 1996, and 2 July and 21 August 1997.

${ }^{\mathrm{z}} \mathrm{GS}=$ Growth stage: plants sampled at panicle emergence, stigma emergence, milk stage of grain fill, or hard dough stage of grain maturation. 
growth stages, and stalks within a plant, as well as with year by date of planting and year by growth stage interactions (Table 1). Incidence among stalks was greatest in the later growth stages in each experiment except for the first date of planting in 1997 (Table 2). B. setariae was isolated from a mean of $9.2 \%$ of the nodes. Frequency of isolation from nodes differed between growth stages and with the date of planting by growth stage interaction (Table 1). Isolations from nodes were greatest at the dough stage of growth in each experiment except for the first date of planting in 1997 (Table 2). At the dough stage, B. setariae tended to be isolated from the lower and middle nodes of the plant (Fig. 2). Over all experiments, its isolation from the lower and middle nodes was correlated with discoloration of those nodes (Table 3 ). Isolation frequency for $B$. setariae within a stalk was correlated with rust severity ( $r=$ $0.66, P<0.01$ ).

Curvularia spp. were isolated from $51.4 \%$ of the stalks collected, and incidence of infected stalks differed between dates of planting, and with year by date of planting and year by growth stage interactions (Table 1). Incidence among stalks was lower in the later growth stages in the first date of planting in 1996, but no differences existed among growth stages in other experiments (Table 2). Curvularia spp. were isolated from $7.0 \%$ of the nodes. Frequency of isolation from nodes differed by year, date of planting, stalk within a plant, and year by date of planting, year by growth stage, and date of planting by growth stage interactions (Table 1). Frequency of isolation from nodes was lower in the later planting dates of both years. Frequency of isolation from nodes was lower as plants matured in the first date of planting in 1996 and was greater as plants matured in the first date of planting in 1997. No differences in isolation frequency from nodes were observed among the growth stages within the second date of planting in either year (Table 2). Isolation of Curvularia spp. was rarely correlated with node discoloration, and when a relationship existed, the correlation coefficient was negative (Table 3). Isolation frequency for Curvularia within a stalk was likewise negatively correlated with rust severity ( $r=$ $-0.19, P<0.05)$.

Alternaria spp. were isolated from $33.6 \%$ of the stalks collected, and incidence of infected stalks differed between dates of planting and growth stages, as well as with year by date of planting, year by growth stage, and date of planting by growth stage interactions (Table 1). Incidence among stalks was greater in the later growth stages in the first date of planting in 1996, but was inconsistent across all other year by date of planting experiments (Table 2). Alternaria spp. were isolated from $6.9 \%$ of the nodes. Frequency of isolation from nodes differed by year, date of planting, and growth stage, and with all two- and three-factor interactions (Table 1). The isolation frequency from $50.0 \%$ of the nodes at the milk stage in the second date of planting in 1997 was considerably higher than the mean isolation rate of $4.2 \%$ at all other sampling times (Fig. 3). Apart from this possibly anomalous data, a greater isolation frequency from the latter growth stages in the first date of planting in 1996 was the only discernable trend. Isolation of Alternaria spp. from nodes was frequently correlated with discoloration of the nodes (Table 3). Isolation frequency for Alternaria spp. within a stalk was correlated with rust severity $(r=0.29$, $P<0.01)$.

Several other fungi were isolated from the nodes at low frequencies (in parentheses) including: Rhizopus spp. (5.9\% of the nodes), Epicoccum spp. (3.6\%), F. chlamydosporum (3.4\%), Nigrospora spp. (3.3\%), Pythium spp. (3.1\%), Myrothecium verracaria (Alb. \& Schw.) Ditm. Ex Fr. (2.8\%), Penicillium spp. (2.7\%), Fusarium equiseti (Corda) Sacc. Sensu Gordon (2.3\%), Phyllosticta penicillariae (1.4\%), and Exserohilum rostratum (1.2\%). Fungi isolated from $\leq 1 \%$ of the nodes included: Gloeocercospora sorghi Bain \& Edgerton, Fusarium graminearum, F. solani (Mart.) Appel \& Wollenw. emend Snyd. \& Hans, F. sporotrichioides Sherb., unidentified Fusarium species, Drechslera dematioidea, D. triseptata (Drechsler) Subram. \& Jain, unidenti-

Table 2. Means ${ }^{v}$ for rust severity (\% foliage) and incidence, among stalks or among nodes within stalks, of discolored nodes and isolation of specific fungi from stalks of pearl millet HGM 100 grown at Tifton, GA, in 1996 and 1997

\begin{tabular}{|c|c|c|c|c|c|c|c|c|c|c|c|c|}
\hline \multirow{3}{*}{$\begin{array}{l}\text { Growth } \\
\text { stage }\end{array}$} & \multirow{3}{*}{$\begin{array}{c}\text { Rust } \\
\text { severity } \\
(\%)\end{array}$} & \multicolumn{11}{|c|}{ Incidence $(\%)$ of stalks or nodes ${ }^{w}$} \\
\hline & & \multirow{2}{*}{$\begin{array}{c}\begin{array}{c}\text { Discol- } \\
\text { oration }\end{array} \\
\text { Nodes }\end{array}$} & \multicolumn{2}{|c|}{$\begin{array}{c}\text { Fusarium } \\
\text { moniliforme }\end{array}$} & \multicolumn{2}{|c|}{$\begin{array}{c}\text { Fusarium } \\
\text { semitectum }\end{array}$} & \multicolumn{2}{|c|}{ Bipolaris setariae } & \multicolumn{2}{|c|}{ Curvularia spp. } & \multicolumn{2}{|c|}{ Alternaria spp. } \\
\hline & & & Stalks & Nodes & Stalks & Nodes & Stalks & Nodes & Stalks & Nodes & Stalks & Nodes \\
\hline \multicolumn{13}{|c|}{1996 DOPx $^{x}$} \\
\hline Panicle & $1.3 \mathrm{c}^{\mathrm{y}}$ & $10.9 \mathrm{~b}$ & 60 & $9.1 \mathrm{~b}$ & $10 \mathrm{~b}$ & $1.0 \mathrm{~b}$ & $40 \mathrm{~b}$ & $4.5 \mathrm{~b}$ & $80 \mathrm{ab}$ & $12.7 \mathrm{a}$ & $0 \mathrm{~b}$ & $0.0 \mathrm{~b}$ \\
\hline Stigma & $2.4 \mathrm{c}$ & $12.7 \mathrm{~b}$ & 90 & $13.6 \mathrm{~b}$ & $30 \mathrm{~b}$ & $2.7 \mathrm{~b}$ & $50 \mathrm{ab}$ & $4.5 \mathrm{~b}$ & $100 \mathrm{a}$ & $17.3 \mathrm{a}$ & $0 \mathrm{~b}$ & $0.0 \mathrm{~b}$ \\
\hline Milk & $35.0 \mathrm{~b}$ & $42.7 \mathrm{a}$ & 80 & $17.3 \mathrm{~b}$ & $100 \mathrm{a}$ & $28.2 \mathrm{a}$ & $80 \mathrm{ab}$ & $10.9 \mathrm{~b}$ & $40 \mathrm{c}$ & $3.6 \mathrm{~b}$ & $70 \mathrm{a}$ & $10.9 \mathrm{a}$ \\
\hline Dough & $80.5 \mathrm{a}$ & $56.4 \mathrm{a}$ & 80 & $31.8 \mathrm{a}$ & $100 \mathrm{a}$ & $26.4 \mathrm{a}$ & $90 \mathrm{a}$ & $28.2 \mathrm{a}$ & $50 \mathrm{bc}$ & $5.5 \mathrm{~b}$ & $60 \mathrm{a}$ & $10.0 \mathrm{a}$ \\
\hline \multicolumn{13}{|c|}{1996 DOP2 } \\
\hline Panicle & $0.2 \mathrm{c}$ & $12.0 \mathrm{~d}$ & 80 & 21.0 & $40 \mathrm{ab}$ & $10.0 \mathrm{ab}$ & $20 \mathrm{~b}$ & $2.0 \mathrm{~b}$ & 50 & 6.0 & $10 \mathrm{~b}$ & $1.0 \mathrm{~b}$ \\
\hline Stigma & $0.9 \mathrm{c}$ & $24.0 \mathrm{c}$ & 100 & 21.0 & $20 \mathrm{~b}$ & $2.0 \mathrm{~b}$ & $10 \mathrm{~b}$ & $2.0 \mathrm{~b}$ & 30 & 3.0 & $70 \mathrm{a}$ & $8.0 \mathrm{a}$ \\
\hline Milk & $12.0 \mathrm{~b}$ & $40.0 \mathrm{~b}$ & 70 & 27.0 & $70 \mathrm{a}$ & $15.0 \mathrm{a}$ & $60 \mathrm{a}$ & $8.0 \mathrm{~b}$ & 30 & 5.0 & $40 \mathrm{ab}$ & $7.0 \mathrm{ab}$ \\
\hline Dough & $74.5 \mathrm{a}$ & $63.0 \mathrm{a}$ & 90 & 18.0 & $50 \mathrm{ab}$ & $5.0 \mathrm{ab}$ & $90 \mathrm{a}$ & $39.0 \mathrm{a}$ & 60 & 7.0 & $10 \mathrm{~b}$ & $1.0 \mathrm{~b}$ \\
\hline \multicolumn{13}{|c|}{1997 DOP1 } \\
\hline Panicle & $0.0 \mathrm{~b}$ & $12.7 \mathrm{c}$ & 70 & $14.5 \mathrm{c}$ & 70 & 11.8 & 10 & 0.9 & 40 & $3.6 \mathrm{c}$ & 30 & 5.5 \\
\hline Stigma & $0.0 \mathrm{~b}$ & $20.9 \mathrm{bc}$ & 100 & $28.2 \mathrm{bc}$ & 70 & 11.8 & 30 & 2.7 & 60 & $6.4 \mathrm{bc}$ & 10 & 0.9 \\
\hline Milk & $0.6 \mathrm{~b}$ & $23.6 \mathrm{~b}$ & 90 & $42.7 \mathrm{ab}$ & 60 & 9.1 & 0 & 0.0 & 80 & $12.7 \mathrm{ab}$ & 10 & 0.9 \\
\hline Dough & $2.1 \mathrm{a}$ & $34.5 \mathrm{a}$ & 80 & $51.8 \mathrm{a}$ & 80 & 18.2 & 30 & 3.6 & 60 & $15.5 \mathrm{a}$ & 10 & 0.9 \\
\hline \multicolumn{13}{|c|}{1997 DOP2 } \\
\hline Panicle & $\ldots^{\mathrm{z}}$ & $\ldots$ & $\ldots$ & $\ldots$ & $\ldots$ & $\ldots$ & $\ldots$ & $\ldots$ & $\ldots$ & $\ldots$ & $\ldots$ & $\ldots$ \\
\hline Stigma & $\ldots$ & $\ldots$ & $\ldots$ & $\ldots$ & $\ldots$ & $\ldots$ & $\ldots$ & $\ldots$ & $\ldots$ & $\ldots$ & $\ldots$ & $\ldots$ \\
\hline Milk & 49.5 & 84.0 & 80 & 16.0 & 50 & 5.0 & $0 \mathrm{~b}$ & $0.0 \mathrm{~b}$ & 20 & 2.0 & $100 \mathrm{a}$ & $50.0 \mathrm{a}$ \\
\hline Dough & 48.0 & 73.0 & 100 & 26.0 & 60 & 15.0 & $90 \mathrm{a}$ & $33.0 \mathrm{a}$ & 20 & 2.0 & $50 \mathrm{~b}$ & $6.0 \mathrm{~b}$ \\
\hline
\end{tabular}

${ }^{v}$ Values are means derived from a total of 10 stalks (two stalks from each of five plants) sampled at the indicated growth stages. Rust severities are visual estimates of percentage of foliage infected with or necrotic due to rust.

${ }^{\mathrm{w}}$ Stalks $=$ incidence $(\%)$ of stalks with discoloration or incidence of stalks from which a particular fungus was isolated. Nodes $=$ incidence $(\%)$ of nodes within a stalk with discoloration or incidence of nodes within a stalk from which a particular fungus was isolated.

x DOP = date of planting: 12 July and 5 August 1996, and 2 July and 21 August 1997.

${ }^{\text {y }}$ Numbers within a column within a date of planting followed by the same letter are not significantly different at $P=0.05$ according to Fisher's least significant difference test.

${ }^{\mathrm{z}}$ Data are not available. 
fied "Helminthosporium"-type species, Rhizoctonia zeae, R. solani, Cladosporium spp., Cordana spp., Pestalotia spp., Trichoderma spp., Aspergillus flavus Link:Fr., and other unidentified species.

\section{DISCUSSION}

Although many different fungi were isolated from these pearl millet stalks, certain fungi tended to predominate. In the 1995 isolations, the distribution of isolation of $B$. setariae from discolored nodes was similar to the distribution of discolored nodes, and sources of variation in the analyses of discoloration and fungal isolations were similarly significant. Despite these similarities, B. setariae was not the sole fungus associated with stalk rot. Frequency of node discoloration, and isolation of $F$. semitectum and $F$. moniliforme, increased in later sampling dates, whereas isolation of $B$. setariae decreased at the final sampling. Information obtained in 1995 was limited because isolations were made only from symptomatic (discolored) nodes and nei-
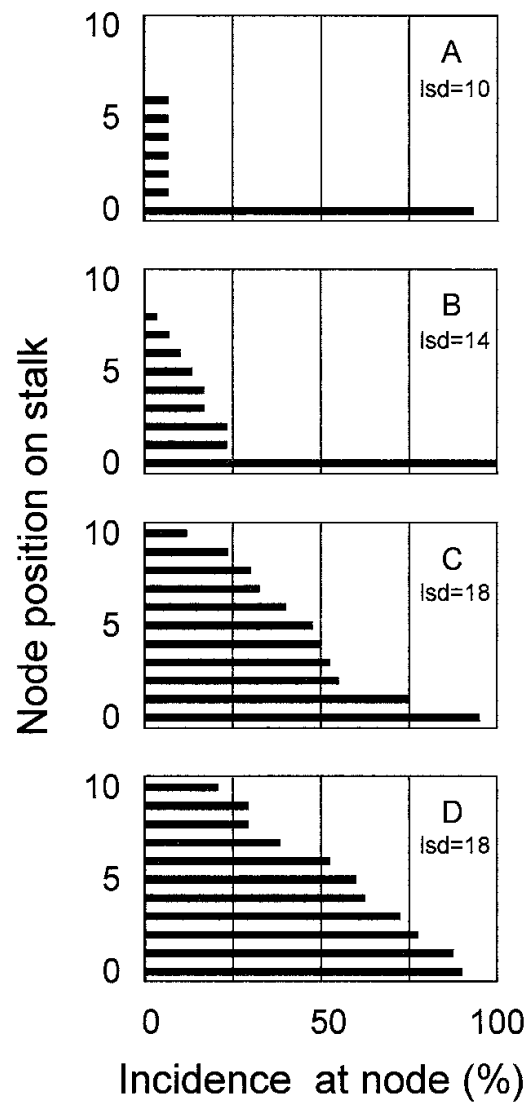

Fig. 2. Distributions of discolored nodes in stalks of pearl millet HGM 100 sampled at four growth stages from two dates of planting in 1996 and 1997. $\mathbf{A}=$ panicle emergence, $\mathbf{B}=$ stigma emergence, $\mathbf{C}=$ grain at milk stage, $\mathbf{D}=$ grain at hard dough stage. Node $0=$ base of plant and node $10=$ highest node on the stalk. Values are means of observations from 30 stalks of the first two growth stages, and 40 stalks from plants at the latter two growth stages. LSD values are Fisher's LSD values for differences in incidence at nodes $(P=0.05)$. ther growth stage nor rust severity was assessed.

In the experiments conducted in 1996 and 1997, frequency of internal node discoloration and fungal colonization of HGM 100 stalks tended to increase from the base of the plant to the apex with maturation. Isolation of $F$. moniliforme, the predominant fungus, was not correlated with rust severity, and was frequently isolated from asymptomatic nodes. The absence of significant variation associated with year and date of planting affecting its isolation, and the predominance of this fungus within stalks, suggests a relationship exists with pearl millet that is similar to the widespread co-occurrence of related Fusarium species of the Liseola section with corn and sorghum. Previous work indicated that $F$. moniliforme was the predominant fungus in corn and sorghum tissue (7).

F. moniliforme is no longer considered to be a valid species, and relationships among $F$. moniliforme-type fungi have been re-examined. Reproductive barriers (13) and the presence of mating type alleles detected by PCR primers (5) have been used to define mating populations within the Gibberella fujikuroi (Sawada) Ito \& Kimura species complex. The specificity of these mating populations for their pathogenicity to sorghum and pearl millet have not yet been clarified. It is acknowledged that the fungus that infects pearl millet is likely to be different from $F$. verticillioides (Sacc.) Nirenberg (=F. moniliforme Sheldon, teleomorph $=G$. fujikuroi mating population A); however, it is not possible to discern in retrospect which of the closely related fungi within this reclassified species complex is commonly isolated from pearl millet.

Because of the high frequency of colonization of stalks at earlier growth stages and the frequent isolation of the fungus from asymptomatic nodes, $F$. moniliforme appeared to be the primary fungus colonizing pearl millet stalks in the 1996 and 1997 experiments, with $F$. semitectum being a secondary invader. In a previous study, $F$. semitectum and $F$. moniliforme were the fungi most frequently isolated from rust-free stalks of HGM 100 (24). In that study, $F$. semitectum predominated, but $F$. moniliforme was more uniformly distributed within the stalks. Differences in fungal isolations between these two studies may be due to a number of factors, including differences in rust infection and prevailing environmental differences between the two studies.

Fusarium species have been associated with other stalk diseases of pearl millet. Isolation of $F$. poae from diseased stems and inflorescences was reported in India (10). Top rot, also called twisted top or Pokkah Boeng disease, is caused by $F$. moniliforme (or related fungi, as discussed above) and has been reported in India and the United States $(11,20)$. Symptoms of top rot include rotting of immature leaves and panicles within the whorl (20). Similar symptoms were not observed in the present experiments. The presence or extent of internal stalk discoloration in plants with top rot is not known.

Other fungi previously isolated from stalks and common to the present study include $B$. setariae and Alternaria spp. (24). In the present study, the low isolation frequencies of these fungi observed at earlier growth stages changed dramatically by the later growth stages, indicating that these fungi are likely to be secondary colonizers of stalk tissue. Bipolaris species have often been reported to be pathogens of pearl millet seedlings, foliage, and grain (23). B. setariae is known to cause preand post-emergence damping-off and seedling rots $(14,22)$, and plants become more susceptible to foliar infection with maturity (21). In contrast, Alternaria species have rarely been reported to be pathogenic to pearl millet (23). In the present experiments, isolations of B. setariae and Alternaria spp. were associated with grain fill, high levels of rust infection, and visible

Table 3. Pearson's correlation coefficients ${ }^{\mathrm{x}}$ between presence of internal node discoloration and isolation of fungi from that node in stalks of pearl millet HGM 100 grown at Tifton, GA, in 1996 and 1997

\begin{tabular}{lccccc}
\hline & \multicolumn{4}{c}{ Correlation between discoloration at a node and isolation of } \\
\cline { 2 - 5 } Node $^{y}$ & $\begin{array}{c}\text { Fusarium } \\
\text { moniliforme }\end{array}$ & $\begin{array}{c}\text { Fusarium } \\
\text { semitectum }\end{array}$ & $\begin{array}{c}\text { Bipolaris } \\
\text { setariae }\end{array}$ & $\begin{array}{c}\text { Curvularia } \\
\text { spp. }\end{array}$ & $\begin{array}{c}\text { Alternaria } \\
\text { spp. }\end{array}$ \\
\hline 10 & $0.22^{* \mathrm{z}}$ & 0.17 & $0.23^{*}$ & 0.10 & $0.42^{* *}$ \\
9 & $0.23^{* *}$ & 0.07 & 0.06 & -0.05 & $0.18^{*}$ \\
8 & $0.17^{*}$ & 0.01 & 0.11 & -0.07 & $0.31^{* *}$ \\
7 & $0.22^{*}$ & $0.19 *$ & 0.13 & -0.14 & $0.25^{* *}$ \\
6 & 0.06 & -0.04 & $0.24 * *$ & 0.04 & $0.30^{* *}$ \\
5 & 0.01 & 0.07 & $0.23^{* *}$ & $-0.17^{*}$ & $0.30^{* *}$ \\
4 & -0.06 & 0.07 & $0.42^{* *}$ & -0.05 & $0.24^{* *}$ \\
3 & -0.10 & -0.03 & $0.40^{* *}$ & 0.01 & $0.28^{* *}$ \\
2 & 0.07 & 0.10 & $0.35^{* *}$ & $-0.17 *$ & 0.15 \\
1 & 0.12 & 0.15 & 0.14 & 0.04 & $0.20^{*}$ \\
0 & $0.19 *$ & 0.06 & 0.02 & 0.11 & 0.04 \\
\hline
\end{tabular}

${ }^{x}$ Correlations were calculated from data of 140 samples at each node.

y Node $10=$ uppermost node, node $1=$ lowest node, node $0=$ base of plant.

$\mathrm{z} *$ and $* *$ indicate a significant correlation coefficient at $P=0.05$ and 0.01 , respectively. 
internal stalk rot (discoloration of the nodes). These fungi appear to be primarily associated with stalk rots of rust-infected HGM 100 in 1996 and 1997.

The increased frequency of node discoloration in and fungal isolation from stalks tends to correspond with the stage of plant growth at which lodging commonly occurs (26). In the present experiments, the distributions of discoloration and fungi within stalks was more easily quantified based on node position. Although discoloration first appeared in the nodes, it subsequently spread into and through the internode tissue. Decomposition of internal stalk tissue followed symptoms of discoloration. Lodging is a late manifestation of disease, resulting from decomposition of internal stalk tissue.

Information concerning other stalkrotting fungi of pearl millet is limited. Charcoal rot, caused by Macrophomina phaseolina, has been reported in Botswana (2) and India (15). In India, lesions developed just above the first node and plants were frequently killed before flowering when grown under drought-stressed conditions. Similar symptoms have not been observed in the southeastern United States, despite the presence of this pathogen on corn in this region.
In Florida, infection of pearl millet roots, stalks, leaf sheaths, and leaves by $R$. solani resulted in lodging (19). Infection by Sclerotium rolfsii was also observed in water-soaked stalk tissue, which darkened and gradually dried to a dark brown color. Sclerotia frequently developed on host tissue. Both pathogens were isolated from stalks in the present study, but not at frequencies great enough for them to be considered as significant contributors to stalk rot under the conditions of these experiments.

Stalk rot of pearl millet in these experiments was associated with a complex of several fungi whose incidence was influenced by rust infection, plant maturation, and environmental factors associated with year and date of planting. This study provides only a limited understanding of the etiology of the disease. Attempts to develop pathogenicity assays for the fungi isolated from these studies have not been successful, possibly due to the inability to reproduce in the greenhouse the necessary stress associated with severe rust infection required to predispose the host to stalk rot. As new pearl millet hybrids are grown for grain across a wider range of environments, and as techniques for resistance screening are developed, a greater under- standing of the stalk rot complex will emerge.

\section{ACKNOWLEDGMENT}

I thank Trevor Perla for his technical assistance.

\section{LITERATURE CITED}

1. Barnett, H. L., and Hunter, B. B. 1972. Illustrated Genera of Imperfect Fungi. 3rd ed. Burgess, Minneapolis, MN

2. Botswana Ministry of Agriculture. 1987. Annual report for the division of arable crops research 1985-86. Department of Agricultural Research, Agricultural Research Station, Sebele, Botswana.

3. Ellis, M. B. 1971. Dematiaceous Hyphomycetes. Commonwealth Mycological Institute, Kew, Surrey, England.

4. Hanna, W. W. 1993. Registration of pearl millet parental lines Tift 8677 and $\mathrm{A}_{1} / \mathrm{B}_{1}$ Tift90E 1 . Crop Sci. 33:1119.

5. Kerényi, Z., Zeller, K., Hornok, L., and Leslie, J. 1999. Molecular standardization of mating type terminology in the Gibberella fujikuroi species complex. Appl. Environ. Microbiol. 65:4071-4076.

6. Klich, M. A., and Pitt, J. I. 1988. A laboratory guide to the common Aspergillus species and their teleomorphs. CSIRO Division of Food Processing, North Ryde, Australia.

7. Leslie, J. F., Pearson, C. A. S., Nelson, P. E., and Toussoun, T. A. 1990. Fusarium spp. from corn, sorghum, and soybean fields in the central and eastern United States. Phytopathology 80:343-350.

8. Nelson, P. E., Toussoun, T. A., and Marasas, W. F. O. 1983. Fusarium Species. An Illus-
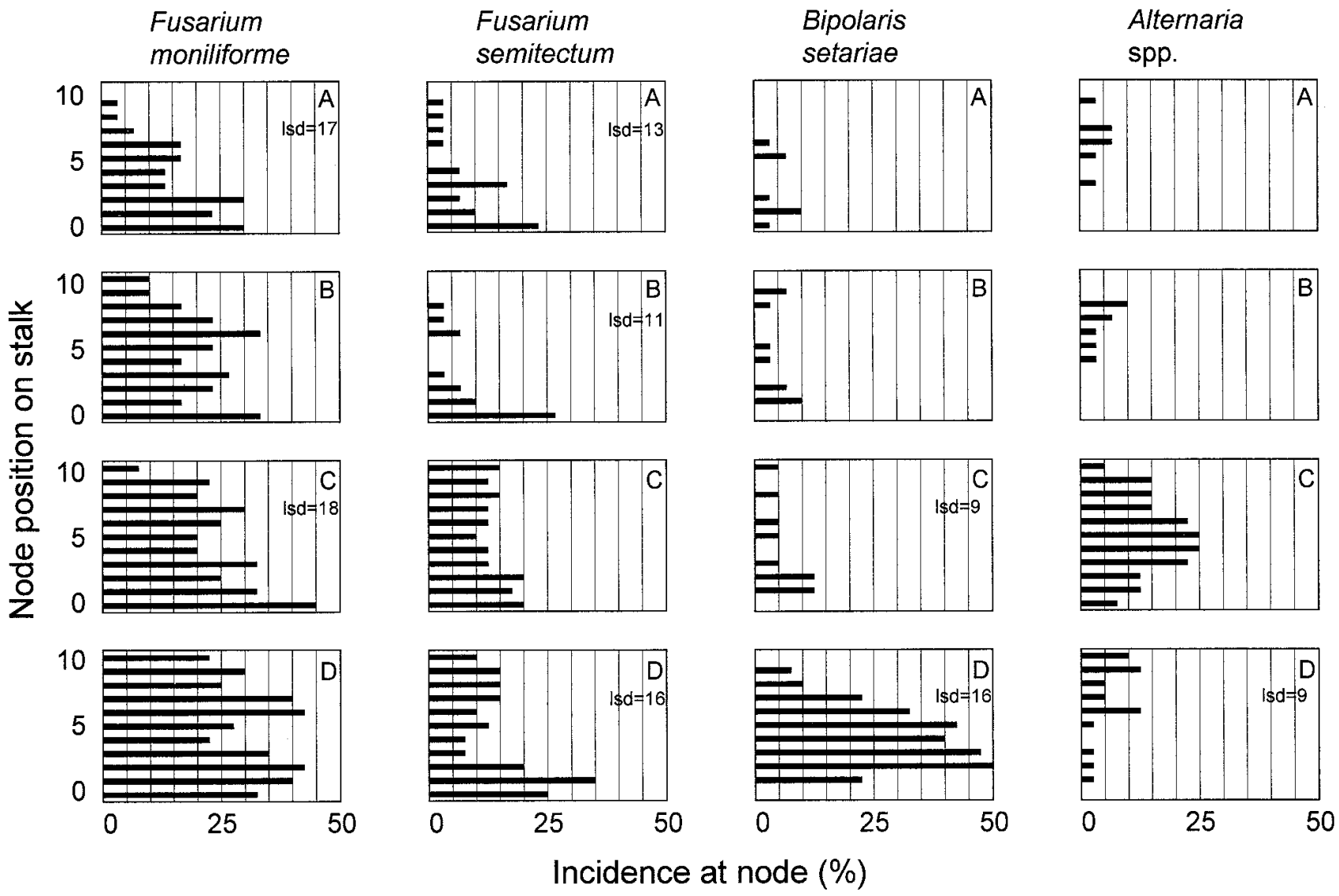

Fig. 3. Distributions of isolations of predominant fungi from stalks of pearl millet HGM 100 sampled at four growth stages from two dates of planting in 1996 and 1997. A = panicle emergence, $\mathbf{B}=$ stigma emergence, $\mathbf{C}=$ grain at milk stage, $\mathbf{D}=$ grain at hard dough stage. Node $0=$ base of plant, and node $10=$ highest node. Values are means of observations from 30 stalks of the first two growth stages and 40 stalks from plants at the latter two growth stages. LSD values are Fisher's LSD values for differences in incidence at nodes $(P=0.05)$. If no LSD values are indicated, no difference exists for isolation frequency between nodes. 
trated Manual for Identification. Pennsylvania State University Press, University Park.

9. O'Donnell, K. L. 1979. Zygomycetes in Culture. Palfrey Contributions in Botany No. 2. University of Georgia, Athens.

10. Ramakrishnan, K., and Subramanian, C. V. 1952. The fungi of India - A second supplement. J. Madras Univ. B. 22:1-65.

11. Ramakrishnan, T. S. 1941. Top-rot ('twisted top' or 'pokkah bong') of sugarcane, sorghum, and cumbu. Curr. Sci. 10:406-408.

12. Saccas, A. M. 1954. Les champignons parasites des sorghos (Sorghum vulgare) et des pénicillaires (Pennisetum typhoideum) en Afrique Équatorial Française. Agron. Trop. 9:647-686

13. Samuels, G. J., Nirenberg, H. I., and Seifert, K. A. 2000. Perithecial Species of Fusarium. Fusarium: Paul E. Nelson Memorial Symposium. B. A. Summerell, J. F. Leslie, D. Backhouse, W. L. Bryden, and L. W. Burgess, eds. American Phytopathological Society, St. Paul, MN.

14. Shetty, H. S., Mathur, S. B., Neergaard, P., and Safeeulla, K. M. 1982. Drechslera se- tariae in Indian pearl millet seeds, its seedborne nature, transmission and significance. Trans. Br. Mycol. Soc. 78:170-173.

15. Singh, G., Thakur, R. P., and Weltzien, R. 1997. Dry stalk rot - a new disease of pearl millet in Rajasthan. Int. Sorghum Millets Newsl. 38:124-128.

16. Sivanesan, A. 1987. Graminicolous species of Bipolaris, Curvularia, Drechlsera, Exserohilum, and their teleomorphs. Commonw. Mycol. Inst. Mycol. Pap. 158. Kew, Surrey, England.

17. Sneh, B., Burpee, L., and Ogoshi, A. 1991. Identification of Rhizoctonia Species. American Phytopathological Society, St. Paul, MN.

18. Tapsoba, H., and Wilson, J. P. 1996. Pathogenic variation in Puccinia substriata var. indica in the southeastern United States and screening for resistance in pearl millet germ plasm. Plant Dis. 80:395-397.

19. Weber, G. F. 1963. Pellicularia spp. pathogenic on sorghum and pearl millet in Florida. Plant Dis. Rep. 47:654-656.

20. Wells, H. D. 1956. Top rot of pearl millet caused by Fusarium moniliforme. Plant Dis.
Rep. 40:387.

21. Wells, H. D., and Burton, G. W. 1967. Helminthosporium setariae on pearl millet, Pennisetum typhoides, as affected by age of host and host differences. Crop Sci. 7:621-622.

22. Wells, H. D., and Winstead, E. E. 1965. Seedborne fungi in Georgia-grown and westerngrown pearl millet seed on sale in Georgia during 1960. Plant Dis. Rep. 49:487-489.

23. Wilson, J. P. 1999. Pearl Millet Diseases: A Compilation of Information of the Known Pathogens of Pearl Millet, Pennisetum glaucum (L.) R. Br. U.S. Dep. Agric. Agric. Res. Serv., Agric. Handb. No. 716.

24. Wilson, J. P., Cunfer, B. M., and Phillips, D. V. 1999. Double-cropping and crop rotation effects on diseases and grain yield of pearl millet. J. Prod. Agric. 12:198-202.

25. Wilson, J. P., and Gates, R. N. 1999. Disease resistance and biomass stability of forage pearl millet hybrids with partial rust resistance. Plant Dis. 83:733-738.

26. Wilson, J. P., Hanna, W. W., and Gascho, G. J. 1996. Pearl millet grain yield loss from rust infection. J. Prod. Agric. 9:543-545. 